\title{
Ethical Aspects of Social Research: Old Concerns in the Face of New Challenges and Paradoxes. A Reflection from the Field of Biographical Method
}

\author{
Kaja Kaźmierska \\ University of Lodz, Poland
}

DOI: http://dx.doi.org/10.18778/1733-8077.16.3.08

\section{Keywords:}

Ethical Concerns;

Archiving;

Big Qualidata;

Biographical Research

\begin{abstract}
The paper deals with the ethical aspects of the research process and contemporary changes in this field, which make the discussion on ethical dilemmas and concerns more dynamic and varied. Although in natural science and social sciences one can find a common ground related to the most general ethical principles. In the article I refer primarily to the social sciences. The article discusses three aspects affecting the dynamics of ethical discussions: the development of research in the field of natural sciences leading to many ethical dilemmas and forcing ethical codification of research proceedings also in the area of social sciences; the increase in sensitivity and social consciousness and not only awareness of research as such (processes of democratization, emphasizing human and animal rights, protection of minority rights, the process of individualization); the dynamics of contemporary social changes resulting from the development of technology, especially the Internet, which has become a global resource of data and their exchange. This forces qualitative researchers to consider the issue of data archiving, their reanalysis, and determining the boundary for creating Big Qualidata from them. The article discusses these three dimensions, with particular emphasis on the last of them, which will be commented on in relation to the specific methodological approach, which is biographical research.
\end{abstract}

Kaja Kaźmierska, PhD, a Professor at the University of Lodz, head of the Department of Sociology of Culture, Institute of Sociology, Faculty of Economics and Sociology at the University of Lodz, Poland, and a director of the Institute of Sociology. She specializes in biographical research, identity, and biographical memory. She is the author of the books: Polish Wartime Experiences and Shaping of Ethnic Identity. The Analysis of Borderline Narratives (IFiS PAN, Warsaw 1999), Biography and Memory: The Generational Experience of the Shoah Survivors (Academic Studies Press, Boston 2012). She has edited a selection of texts entitled Biographical Method in Sociology. Anthology of Texts (Nomos, Cracow 2012). The co-author (with Katarzyna Waniek and Agata Zysiak) of the book Tell the University. Academic Lodz in Biographies Inscribed in the History of the University of Lodz (Wydawnictwo Uniwersytetu Łódzkiego, Lodz 2015) and recently published (with Jarosław Pałka) Soldiers of the Polish Army. Oral History (Wydawnictwo Uniwersytetu Łódzkiego, Lodz 2018).

email address: kaja.kazmierska@uni.lodz.pl 


\section{Introductory Remarks}

The ethical aspects of research have always been a matter of reflection, especially for ethicists and philosophers of science. Recently, however, the discussion on ethical dilemmas and concerns seems to be more dynamic and varied. These days we can observe, especially in Anglo-Saxon literature and only slightly less frequently in Polish literature, a significant increase in the interest in this issue and a broadening reflection in both natural and social sciences encompassing the thoughts of researchers who directly, for instance, in the course of research, experience specific ethical dilemmas. As a result, nowadays, it is hard to reduce research ethics to issues related to different aspects of misconduct in science, which could be represented by fabrication, falsification, or plagiarism ${ }^{1}$ (Galewicz 2009:48). In the article, I refer primarily to the social sciences. Although, of course, in both types of sciences one can find a common ground related to the most general ethical principles which should apply to everyone. However, this discussion seems to be already behind us. Therefore, more and more attention is not paid to general indications, which may take the form of general standards of conduct (although in practice sometimes not much may result from them), and it is becoming more important to focus on the issues more directly related to conducting research. And, here, the distinction between natural sciences and social sciences frames the reflection.

Thus, where does this contemporary ethics discourse come from? In my opinion, this is due to several reasons. Firstly, "putting the problem on the agenda" by transferring procedures from natural sciences, in

\footnotetext{
${ }^{1}$ This, of course, does not mean that these issues as such have ceased to be important.
}

the field of which, until some point, ethical issues were hardly considered at all. The development of ethical reflection occurred along with the accelerated development of science, especially in relation to those aspects of research work which were directly related to the study of human behavior, interference in the human body, or experiments carried out on animals and sometimes on people. The period of fascination with the possibilities of science and its development, especially in the positivist paradigm, was a time of medical, but also social, experiments (e.g., in the field of social psychology). This has provided us with a lot of valuable knowledge, but at the same time could raise concerns. From today's perspective, this could simply arouse many ethical reservations. Certainly, they could not be carried out today. We have now come to a deeper reflection on not only what is ethical and what is not, but what is allowed and what is not. At the same time, this does not obscure significant ethical dilemmas. With the development of experimental sciences they seem to be growing. This has resulted in numerous regulations in the form of codes of ethics, committees of ethics giving permission to conduct research. These practices were implemented into social sciences, sometimes in the exact form, not taking into account the specifics of doing social research, for instance, its distinctiveness from research in the field of natural sciences.

Secondly, the interest in ethical issues is associated with the increase in sensitivity and social consciousness and not only awareness of research as such. Just as the first reason translated into the institutional dimension of doing science is associated with the process of institutionalization of contemporary social reality, so can the other one be associated with cultural and social changes. These include the processes of democratization and em- 
phasizing human rights, including the protection of minority rights, the individualization process, et cetera. Within this perspective, we may be dealing with the desire to minimize the asymmetry of the roles of the researcher and the participant, making the researcher an equal partner of interaction and co-creator of the research process. Some go further turning this attitude into assumptions of new ethics called alternative.

Finally, the third reason, in my opinion the one which most activates the ethical discussion, especially in the field of social sciences, is the dynamics of contemporary social changes resulting from the development of technology. The development of the Internet, which has become a global resource of data and their exchange, forces qualitative researchers to take a stand on the issue of data archiving, their reanalysis, and determining the boundary for creating qualitative Big Data, which in qualitative research are called Big Qualidata. What is more, the situation of the participant as a person for whom the researcher is to guarantee anonymity often changes. In the era of a bigger or smaller presence of each of us in virtual reality, it is becoming more and more difficult to ensure anonymity. And, a complete change in the profile of the participant in the situation of qualitative research may deprive empirical data of the context, very important in this perspective, and thus the methodological sense. Another no less important factor is the fact that the Internet is not only a communication tool, but also a specific technological solution for data storage. Regarding empirical data, it enables their storage for personal use and, above all, archiving. Digitization of data, formulated a few years ago as a potential condition for receiving grant funding, has now become a matter of institutional and individual obviousness. We all have everything in our computers and clouds. It is a matter of deciding to whom and how we will make our materials available and sometimes we have to face the loss of them when devices fail and we have not made backup copies.

My intention in this text is to refer to three indicated dimensions, with particular emphasis on the last of them, which will be commented on in relation to the specific methodological approach, that is biographical research. This is dictated by two considerations. First of all, I think that the assumptions of normative ethics should be confronted with applied ethics especially concerning social sciences, the main part of which is empirical research. And, this is not related to the relativization of one towards the other, but rather to the realization that the model indications are each time verified by research material, which in the case of social sciences is the social reality. In other words, it happens that strict compliance with ethical codes does not guarantee actual ethical behavior. ${ }^{2}$ Therefore, it is good to consider ethical concerns using the example of particular research problems framed by specific methodology. Secondly, I choose the biographical perspective because I have been working with this method for years. Thus, my comments are the result of my own experiences, observations, and, above all, personally experienced dilemmas. To some extent, referring to Socratic maxim, "I know that I know nothing," the longer I conduct biographical research, the more dilemmas can arise, and the necessity to meet new challenges of the present day is also significant. I also treat this article as a continuation of the text published in 2018 (see: Kaźmierska 2018). The subject of both is the reflection on ethical issues in biographical research, which I treat as a voice in the discussion.

\footnotetext{
2 This can be shown using the example of the discussion around informed consent, which I write more about elsewhere (Kaźmierska 2018).
} 
In the first part of the text, I will focus on synthetic signaling of the first two reasons I have indicated for intensifying discussions on ethical issues. However, it is not my aim to reconstruct the ongoing discussion in the field of ethics, especially in qualitative research. What I intend to do is to outline the general background for the issues presented later in the article. Only, they seemingly do not connect with the next main part of the text. I consider them to be an important background to further considerations which are shaped by the ongoing discussions and approaches.

\section{Human and Posthuman Ethics-New/Old Insights}

When reconstructing (in a very general way) the development of ethics discourse in science we can say that it started to be dynamic when general normative ethics appeared to be problematic and when researchers were confronted with specific problems in the field of applied ethics. The starting point in modern sciences was the positivist approach evaluating any acquisition of knowledge according to the assumption that all methods which develop science are allowed (Wawrzyniak 2005:62). The source of this belief was the rationalist Enlightenment tradition which assumed that the multiplication of the wealth of knowledge is an unquestionable assumption (Rancew-Sikora and Cymbrowski 2016:27) while rationality and progress are the fundamental ideals of Western society (Kincaid, Dupré, and Wylie 2007:4). The development of natural sciences which prioritizes the development of science as knowledge of homo sapiens, or better-of humanity, has stopped devoting attention to the ethical dimension of some research and especially to the situation of individuals who were to be subjected to it. One of the significant moments in shaping the discussion on the consequences of this assumption was the publication of Van Rensselaer Potter's Bioethics: Bridge to the Future from 1971 introducing the concept of bioethics. Potter was a biochemist and oncologist. Thus, his ethical reflection was inspired by his research experience: "Mankind is urgently in need of a new wisdom that will provide 'knowledge of how to use knowledge' for man's survival and improvement in the quality of life" (Ventura-Juncá 2011:82). Today, it is difficult to imagine scientific research in the field of medicine without the decisions of bioethics committees. They are one of the elements of comprehensive actions leading to the institutionalization of ethics through the introduction of ethical codes, the ethics committees mentioned, and the obligation to obtain informed consent from the participants. Regulating the behavior of researchers was taking place still in the normative paradigm, hence in a "natural" way "the phenomenon of managing moral processes in institutions appeared, assuming the hierarchy of moral competence...-a new civilizational expression of ethics authorization is the almost mass introduction of codes of ethics in state services, big companies" (Wiśniewski 2005:31), and let us add-in science, including social sciences. The codes mainly refer to normative ethics which in turn give standards for applied ethics. Apart from general ethics regulations, social research ethics should, in my opinion, be considered mainly as an example of applied ethics, especially in qualitative research. This is due to the specificity of social sciences, whose matter is an individual and his/her social behavior. At the same time the problem is that we are dealing with an "inappropriate imposition of a biomedical model of research ethics onto the social sciences.... and the use of technocratic approaches to research ethics" (Mauthner 2019:678). As a result, sometimes, as the 
authors say, "imagined dangers" (Kohn and Shore 2017:236) are formulated against quite typical research based on in-depth interviews and face to face contact with people. ${ }^{3}$ Whereas the first difference between natural sciences and social sciences, especially in the field of qualitative research, is related to contextual and situational character of the last one, it is very difficult to establish general, universal rules and codify the research process without considering its context. This criticism has been expressed by many scholars (e.g., Klockars 2000; Miller and Bell 2002; Wiśniewski 2005; Merrill and West 2009; Kaźmierska 2018). Their main argument is that we cannot directly implant the natural sciences' standards to social sciences. The authors mentioned here form criticism from a "conventional" position. It should also be noted that one of the effects of the discussion and the tension between the standards of natural sciences and the attempt to implement them in social sciences is the emergence of a different ethical approach. The classic one, deriving from the normative perspective, was called conventional or humanist ethics, which means that it focuses on structuring relations be-

\footnotetext{
3 "For example, a research project led by one of the authors on 'Constitutional Reform in New Zealand and Other Commonwealth Countries' entailed in-depth interviews with various categories of experts, including senior civil servants, government ministers, journalists, high court judges, and constitutional experts. However, the ethics committee refused to grant approval for a number of reasons. One of these was summed up in the panel's comments: Recruitment and coercion: Given the status of the PIs [Principal Investigators] and the acknowledged presence of possible special relationships (Section C7) it might be that invited participants would find it difficult to decline. It would be desirable if a recruitment methodology were devised in which (a) a direct approach from the PI was omitted and/or (b) a process in which the PI was unable to ascertain who participated and who did not was put in place (e.g., this information was compartmentalized within the research team). In a design employing purposive sampling, this is not a simple matter, but the Committee would like to know if this could be considered to minimize any likelihood of coercion (Letter from the University of Auckland Human Participants Ethics Committee, 2013)" (Kohn and Shore 2017:236).
}

tween people treated as independent subjects. An important element of this view was the assumption about the unequal power relationship between the researchers and the research subjects. As alternative approaches, posthumanist ethics appeared, which shifts the focus from power relationship "toward the 'world-making' powers of practices of inquiry" (Mauthner 2019:670-671). The participant becomes an active subject in the research process and "there is no separation between finding out the world (the realm of knowledge) and ensuring that no harm is done in the course of such an investigation (the realm of ethics)...Knowledge production is an inherently ethical matter" (Mauthner 2019:680). As Mauthner points out, posthumanist ethics does not invalidate normatively understood research ethics, but at the same time it reconfigures its practices eliminating the asymmetry of power. In studies emerging from the normative paradigm there is a presupposed inequality of roles. It is the researcher who designs the study, its author and executor. The researched person, even if he or she is treated subjectively, remains one of the elements of this project.

A much more radical approach in this respect was presented by Denzin and Giardina (2007:18) who postulating alternative ethics say: "the purpose of research is not the production of new knowledge per se. Rather, the purposes are pedagogical, political, moral, and ethical, involving the enhancement of moral agency, the production of moral discernment, a commitment to praxis, justice, an ethic of resistance, and a performative pedagogy that resists oppression." We can see that the authors neglect the classical aim of knowledge in the frame of rationalist, positivist paradigm. Precisely, they neglect the sense of academic science (Burawoy 2005) and they focus on more than an engaged approach: 
subjects and researchers develop collaborative, public, pedagogical relationships. The walls between subjects and observers are deliberately broken down. Confidentiality disappears, for there is nothing to hide or protect. Participation is entirely voluntary, hence there is no need for subjects to sign forms indicating that their consent is "informed." The activities that make up the research are participatory; that is, they are performative, collaborative, and action and praxis based. Hence, participants are not asked to submit to specific procedures or treatment conditions. Instead, acting together, researchers and subjects work to produce change in the world. [Denzin and Giardina 2007:20]

If we compare this idea with Burawoy's proposal of varied types of social science: academic, but also public or engaged, we can see that he gives an alternative to different ways of building and applying the knowledge. Each way of doing science is related to a slightly different theoretical framework and the idea is to be able to identify it and to know in which framework the research is conducted. Whereas Denzin and Giardina leave no alternative. They are not focused on creating new knowledge, but on promoting local knowledge and unprivileged, socially excluded voices. We can see that such a perspective fits very well with the processes of decolonization, democratization, breaking down barriers and differences. It is also built against the mainstream way of doing science. In fact, it could be treated as a sensitizing strategy which helps to reflect on the research process. Nevertheless, it is difficult to accept this approach at face value, especially if applied to all kinds of qualitative research. Perhaps the alternative ethics could be helpful in fieldwork in local (postcolonial, marginalized, excluded) environments and communities, in the situation when power relationship is clearly defined and extended beyond the research situation, for example, when a researcher represents a powerful part of society. We can treat the ideas of alternative ethics as a sort of laboratory showing the dynamics of relations between the researcher and those who are the subjects. We can also consider the idea of alternative ethics as a critical voice directed towards mainstream normative ethics. At the same time, it should be realized that these procedures also are problematic. First of all, if treating them not as a sort of utopian concept, we can say that:

Despite the tempting simplicity and suggestiveness of the postulates above, the problem of relations between the list of declared values and the world remains unsolved, just like in the case of codes of scientific associations. Creating general declarations and postulates is not directly related to the creation of knowledge about social reality, and even partly opposes it because it involves building a model of social relations which do not exist or are rare and which may prove impossible to implement. Local communities are treated as a model for all other groups. Even if we acknowledge the positive value of utopia for social change, we are not sure whether scientists should be the direct actors of this change. [Rancew-Sikora and Cymbrowski 2016:33-34]

As a remedy for such a polarized presentation of the ethical issues by Rancew-Sikora, Cymbrowski proposes the symbolic interactionism approach. It constitutes a good supplement to the normative and critical perspectives, it allows one to describe and understand the processuality and ambiguity of the modern world because it offers work at the source: on the definition of the problem, while taking into account the diversity of resources and daily practices of institutions that define them (Rancew-Sikora and Cymbrowski 2016:35). I personally find this ap- 
proach closest to my perspective-it does not invalidate normative models, it does not unconditionally emancipate interactive processes, which are also subject to specific rules.

The framework outlining the activities of modern social researchers and ethical perspectives presented here in a nutshell constitutes the background for making specific decisions in the field of ethical choices or reflection on the ethical aspects of the research process. However, in my opinion, what is currently formatting them most is primarily the progress of information technologies which have forced a significant cultural change.

\section{Archiving Biographical Materials-From Negligence to Mindfulness}

When Pierre Nora (1989) claimed that uncertainty as to what kind of knowledge about ourselves could be useful to the next generations would lead us to record the memories of contemporary society uncritically, he perhaps could hardly foresee that what from a historian's perspective he called memory "archival" quickly became the basic data resource collected not for future generations, but for contemporary needs. Therefore, in my opinion, we can observe now a significant cultural shift reorienting the way of our thinking in this respect.

At the time when Nora described the phenomenon of compulsory archiving associated with the transformation of society aimed at dynamizing change and abandoning the reproduction of established forms of social life, he was rather referring to the postfigurative model of society and the "linear" paradigm of knowledge accumulation: from the past, through the present, to the future. Currently, in a prefigurative society of "mysterious children," as Margaret Mead (1970) had put it, technological advances have led to a reversal of knowledge transmission. The basic paradigm which stimulates the transfer of knowledge is its dynamic changeability, while the goals of education are determined primarily by the postulate of pragmatism of knowledge formulated from the perspective of the present and not its autotelicity. Today is no longer about having knowledge for itself, but about having knowledge that could be useful or applied. Therefore, in a way, we are dealing with a certain paradox-we archive data not to preserve knowledge, but to (re)create it. Referring to the hypothesis of cultural lag that refers to the notion that culture takes time to catch up with technological innovations (Ogburn 1922), ${ }^{4}$ it must be said that in this case social action quickly adjusted to technological innovation. Thus, the condition for the archiving boom was the creation of new technologies enabling digitization of empirical data and their unlimited accumulation. With regard to qualitative data and especially biographical research, for the first time in history, we have gained the possibility of unlimited archiving and thus sharing. This applies to both the once collected and digitized materials, as well as autobiographical narrations collected at present. What is more, archiving research has become obligatory, it is most often included in project applications as one of the elements of the research procedure. Natasha Mauthner vividly describes this change. In the article devoted to problems of archiving and data sharing, she wrote:

When I started out my career as a social scientist just a few years earlier in the late 1980s, it was seen as good practice to destroy the research data that we generat-

\footnotetext{
${ }^{4}$ The evolutionist approach is not necessarily close to my heart, yet the presented idea well-represents the described phenomenon.
} 
ed-particularly personal data-once these had been analyzed and written up. And this was reflected in data protection policies adopted by Universities and funding agencies. Now, the notion of "good research practice" was being radically, but uncritically, redefined. We were being asked to take it as given that what was seen as bad practice yesterday was, overnight, turned into good practice. [Mauthner 2014:178]

Perhaps this practice did not necessarily refer to all qualitative materials, ${ }^{5}$ especially biographical ones. They were not destroyed on purpose, yet we may agree that the need for taking care of empirical material for years has been neglected. Referring to biographical research, a lot of data collected by researchers were kept in their offices or homes, sometimes in the form of tape records not even transcribed. Also, not all written autobiographical materials survived. Just to give two examples considering Polish research-in 1992-1994 I took part in the project Biography and National Identity based on biographical narrative interviews conducted with Poles who experienced the Second World War. It was the first project in Poland with the use of tape recorded biographical narrative interviews. After years, on the wave of the archiving movement, we decided to archive both the recordings and transcriptions. It appeared that from more than 70 interviews collected by eight researchers, we could find at our homes and offices only 22 tapes and 57 transcriptions. The still available recordings and transcriptions of the interviews were archived in the years 2013-2014 in the Qualitative Data Ar-

\footnotetext{
${ }^{5}$ It is enough to notice that one of the well-known sets, located in the British scientific environment, is The QUALIDATA Resource Center located in the Department of Sociology at the University of Essex. Established in the mid-1990s, it is now called the Economic and Social Data Service (ESDS). It provides access to a wide range of qualitative data from the social sciences. It contains research projects dating back to 1970.
}

chive in the Institute of Philosophy and Sociology, Polish Academy of Sciences (IFiS PAN). From the present perspective, I may say that the materials have gained additional value not only as sociological data, but also historical (at least in terms of oral history) material-testimonies of the war witnesses generation-the majority of the interviewees had been already dead. I also regret that some recordings disappeared, perhaps the cassettes were used to record other interviews, but it was just a standard practice in those days.

Taking one more step back to the past, we should bear in mind that for a few decades of the $20^{\text {th }}$ century, when neo-positivist and scientific approaches had come to dominate international sociology, the biographical approach was still being cultivated in Poland, mainly due to Florian Znaniecki, who was an influential teacher of a generation of outstanding sociologists, such as Józef Chałasiński and Jan Szczepański, who continued and developed his work. Znaniecki used diverse biographical materials: private letters, written life histories, and written biographical stories on various topics. The last two were usually produced by various competitions organized by institutions, including academic ones. The authors of the best texts were rewarded and the texts were published. This was called "inspired memoir writing" and it became a sort of social action because collecting memoirs "soon became not only an object of academic research, but also a factor of public life" (Szczepański 1982:7). ${ }^{6}$ A number of institutions solely focused on this type of activity, for example, the Polish Academy of Sciences, the Committee on Memoir-Writing, The Society of Friends of

\footnotetext{
${ }^{6}$ Polish sociologists' contributions to biographical research based on collected memoirs have not become well-known due to the language barrier, as all their books were published in Polish (Bertaux 1981:6).
} 
Memoir-Writing storing the memoirs. The collected handwritten documents reached upwards of about 900,000 (Wierzchoś 2008). Due to transition changes after 1989 (causing not only the lack of money, but also interest $)^{7}$ the bulk of the material was neglected and then damaged. In 2002, the remaining documents were rescued by the KARTA Foundation and taken to the National Polish Archives where 165 meters of memoirs manuscripts have been stored (Gluza 2002). This is the example of both concern and negligence. For sure, biographical materials by definition were not destroyed (as described by Mauthner), but at the same time, they were not stored in a proper way.

These two examples show the darker and brighter sides of the past approach to empirical qualitative data, but it is necessary to agree with Mauthner that the definition of "a good practice" has changed in this respect and, to some extent, we should consider such examples as the situation related more to the past issues than present problems.

Nowadays, due to technical development and also awareness changes, the Internet archives are massively created, the role of the interviewee is strengthened, especially if he/she acts as a witness to history. Even if most researchers do not share the radical assumptions of alternative ethics, they strive to overcome or at least weaken the previously described power relation, which has always been

\footnotetext{
7 The lack of interest was caused, first of all, by the fact that some prominent actors of social/political life provided strong institutional support for mentioned institutions and activities. Although it was to some extent ideologically neutral, it was associated with an outgoing system and the diaries themselves were unreliable due to self-censorship. Another reason was that sociologists turned to problems that had been neglected for ideological reasons, and focused on all systemic changes that were taking place in front of their eyes. Researchers also had poor archiving expertise.
}

asymmetrical and put the researcher in a privileged position. At the same time, this optimistic and more reflexive contemporary image also has some drawbacks and generates ethical problems, and this is the problem I would like to devote more attention to.

\section{Big Qualidata Data: Paradoxes of Technological Achievements}

The possibility of archiving and, what is linked to it, aggregating more and more qualitative data can be associated with the Big Data phenomenon, as it was named at the turn of the $20^{\text {th }}$ and $21^{\text {st }}$ centuries, which is based on a combination of analytical theories and modern technology to analyze mass data (Przanowski 2014; Żulicki 2017; Mauthner 2019). Empirical data collected during scientific research projects have a different status because they are collected in order to build knowledge ( $\dot{\mathrm{Z} u-}$ licki 2017:182) in the first place. Secondly, Big Data should be associated primarily with quantitative data. However, it may be noticed that in "some of the ways Big Data discourses, practices and imaginaries are being taken up within qualitative research" (Mauthner 2019:672). The first symptom is using the concept of Big Qualidata and Big QLR (Qualitative Longitudinal Research). The second one is reformatting the way of thinking within qualitative research as if we were dealing with Big Data. Mauthner comments that she first came across this term in 2016 during the workshop entitled BIG QUALIDATA: Tackling Analysis of Very Large Volumes of Qualitative Data in Social Science Research. The main problem was to show the ways of using the software "to address the key question of the workshop." "Can social researchers scaleup techniques of working with qualitative data and meaningfully analyze massively more text 
than they can possibly read?" (Mauthner 2019:693 [emphasis added by author]). Such an assumption completely changes the status of qualitative material, especially in-depth interviews and life stories. After all, the application of these techniques is connected with searching the context and building a vision of the whole Gestalt by the researcher. Even if the final focus is on a fragment of the collected material, the starting point is the knowledge of the whole.

Therefore, we see here a significant reorientation of perceiving qualitative data. One of the differences between quantitative and qualitative data and the corresponding methodologies was in the essential meaning embedded in these terms. Quantitative research is based on large data sets, while qualitative research is based on their limited number and in-depth analysis of the material. The massification of qualitative data can fundamentally change the sense of analysis and research procedures. I wrote about a "softer" change elsewhere (Kaźmierska 2018:396):

One very good example is the conviction that researchers can, or even should, apply new technologies to qualitative research. Computer-based qualitative data analysis software (Q-DAS) has revolutionized qualitative research in this respect. The belief that Q-DAS needs to be utilized has also entered the field of biographical analysis. The main argument, especially among young adepts of biographical research (mainly $\mathrm{PhD}$ students) who are well-acquainted with the new technologies, is that it makes work easier. The conviction is not accompanied by the deeper reflection that computer analysis of narratives is not just the application of a handy tool, but also frames methodological reasoning... Each method entails a different way of conducting an analysis or doing biographical research in particular. Whether it is better or worse will depend on the researcher's purpose and approach-but above all, it will be different. Unfortunately, this aspect of methodological reasoning is very rarely considered. ${ }^{8}$

We can also find an elaborated review of the opinions for and against the use of Q-DAS in Krzysztof Konecki's work (2019:143-146). In the light of Mauthner's view cited above, it can be said that the phenomenon I am describing is not so disturbing, because it can be assumed that researchers using Q-DAS know their material. On the other hand, both Q-DAS and Big Qualidata analyses are part of researchers' characteristic drive to codify, classify, and categorize data. Of course, there is nothing wrong in this, it is more about distributing accents-attaching importance to the categorization of qualitative materials in a similar way as to quantitative data may be due to conscious or unintentional following of the normative paradigm. Already in 1990, a completely different time considering modern technologies (limited access to the Internet, limited methods of computer analysis), Edward Tufte (1990:50) described the process of data grouping in the following way:

pair, merge, harmonize, synthesize, organize, condense, reduce, boil down, choose, categorize, catalog, classify, refine, abstract, scan, look into, idealize, isolate, discriminate, distinguish, screen, sort, pick over, group, pigeonhole, integrate, blend, average, filter, lump, skip, smooth, chunk, inspect, approximate,

\footnotetext{
${ }^{8}$ To contrast, a reverse example can be given when researchers reflect on the possibility of using software in qualitative studies in the frame of phenomenological research: "[w]hile we as qualitative researchers may believe we are actively shaping the use of this software, we ignore at our peril how this software also shapes our research practices, our relationship to research, and ourselves as researchers" (Goble et al. 2012:17).
} 
cluster, aggregate, outline, summarize, itemize, review, dip into, flip through, browse, glance into, leaf through, skim, list, glean, synopsize, winnow, wheat from chaff...

This is a fragment of a more elaborate characteristic, which, let us repeat, was formulated at a time when the technical possibilities of using the indicated methods of data grouping were much more limited. It can, therefore, be imagined that modern technologies strengthen, at least among some researchers, the desire to use them.

Thus, we may be dealing with the first paradox when an individual life story (remaining in the field of biographical research) can become an element of a large data set which a previously designed program will browse for the content which is of a researcher's interest. This is, of course, technically possible, and these solutions are sometimes used on specialized websites (databases) containing biographical materials. For example, the website of the History Meeting House, modern and very well-constructed by the way, has, for instance, such functionality that by typing in the browser, for example, the name of the city or street, we can retrieve fragments of narrations and transcriptions in which this name appears. To be honest, until reading Natasha Mauthner's article, I thought it was a great technological solution since it allows you to view large batches of material. However, I did not take into account the fact that currently this facility can be treated by researchers as the only research strategy, for instance, for some, it may be enough to filter the biographical material without having to read/listen to the entire story. This raises big methodological concerns (why do we need the life story at all?) and, above all, ethical doubts. Meeting the narrator and recording his/her story involves emotional, intellectual, and sometimes physical effort. Someone devotes their time, talks about his/ her life, the narration often launches the process of biographical work, forces a holistic view on his/ her own life. It can be a positive experience, but it can also be related to suffering, an effort to give meaning to one's whole life. In short, it is usually a demanding experience. Each time when asking for a narration, we convince the interviewee that we are interested in his/her life as a unique and unrepeatable constellation of biographical experiences. If we treat this individual story in the manner described above, as an element of Big Qualidata, which the researcher will not read, then this raises serious ethical concerns. It can be said that what constituted the decisive advantage of biographical research in building the researcher-interviewee relationship was not treating the interviewee as a respondent-a machine for answering, but as a narrator to whom the researcher hands over the initiative. ${ }^{9}$ In the situation described above, this frame is again annulled, the context of the relation suspended, and the sense of the autobiographical relation is overlooked. From my observations of research activities within the biographical approach, it follows that the scenario described above is quite probable, especially in the case of younger adepts of biographical research treating virtual reality and technologies creating it as the obvious or even the only possible way of approaching contemporary research tasks. Another group of ethical concerns is related to the area which was previously described as elements of "traditional" ethics, meaning normative ethics. The issue of anonymity returns here like a boomerang. It is becoming

${ }^{9}$ Of course, it is difficult to talk about the total symmetry of the relationship and the abolishment of power in this case. After all, the researcher remained the researcher and the interviewee the research participant. 
increasingly difficult to guarantee anonymity in a situation when almost all of us, whether intentionally or unknowingly, leave a trace on the Internet. Thus, you can make a deliberate search or accidentally google someone. Additionally, "a key ethical issue is that while different data sets may be innocuous on their own, when aggregated, they can compromise people's identities and invade their privacy" (Mauthner 2019:673). For example, “In 2008, a group of researchers publicly released profile data collected from the Facebook accounts of an entire cohort of college students from a US university. While good-faith attempts were made to hide the identity of the institution and protect the privacy of the data subjects, the source of the data was quickly identified, placing the privacy of the students at risk" (Zimmer 2010:313). Of course, there are environments where such identification is more than possible, like these from social media, but it may be also problematic in the case of "traditional" recorded and transcribed narratives. Therefore, this situation generates another paradox-the more we want to respect someone's privacy, the more we tend to anonymize, which results in the dehumanization of the data, and in turn, raises another ethical dilemma. For example, the issue of a broadly informed consent returns-which would guarantee the permission of the participant to use the material beyond the given research situation and the related question if even a broadly informed consent can predict all the future research and analytical situations?

Last but not least, there is one more paradox which leads to further ethical dilemmas. The technical possibilities of collecting and archiving qualitative data, in particular biographical materials, have led to a situation that I call unintended data inflation. In my opinion, there are two dimensions to this in- flation. First of all, duty memory (Nora 1989) ${ }^{10}$ led to increased activity in the field of biographical data and especially oral history. The events which the $20^{\text {th }}$ century abounded with in a natural way helped to search for witnesses to history and collect their accounts. In the last decades of the $20^{\text {th }}$ century, archives began to be massively created. Social and biographical time-a wish to save the memories of the departing generation supported by new technology favored the collection and archiving of life stories. What is more, this activity, along with propagating the witness's story and empowering his/her role in history, is seen as genuinely useful. It is part of the processes of democratization of memory and legitimizing the so-called voice of an ordinary man. It is not only about activities within oral history, but also about interpretive sociology. These motivations and their positive assessment cannot be denied and I am their ardent supporter. At the same time, however, this sometimes compulsive collecting of life stories in the context of intervention projects, for example, saving the memories of witnesses, can paradoxically lead to the deindividualization and objectification of these stories, especially if we consider the storyteller perspective. This is what breeds yet another paradox-we collect accounts to save them from oblivion because we have such technical possibilities (digital recording and archiving). In this way, a positivist, Enlightenment point of view is activated to some extent-the multiplication of the wealth of knowledge is superior to other effects of activities. I admit that I realized this quite recently during one of the biographical seminars when discussing issues related to collec-

\footnotetext{
${ }^{10}$ Duty memory is one of the memory types distinguished by Nora. Duty memory is related to the awareness of the necessity and preservation of the past especially of the marginalized one, excluded from the mainstream memory.
} 
tive and biographical memory about the German camp for Polish children established by the Nazi Germans during the Second World War. ${ }^{11}$ Various post-war circumstances (there is no room for their detailed characteristics) meant that the memory of this camp practically did not exist at the level of the local community-the city of Lodz or in the Polish collective memory, let alone international/ European knowledge. From the perspective of the issues discussed here, I am interested in biographical memory. Almost nobody was interested in the history of the prisoners and their biographies, and if any actions were taken in this regard, they were of an incidental nature. It is within this formulathe restoration of memory-that one of the most dynamic and distinguished foundations in this field has recorded several witness accounts in the form of audio and video. If we were to stop here, we could consider this action a remarkable example worth following-giving voice to history witnesses. The continuation of this story, however, is that all their lives these witnesses were convinced that their history was depreciated, and interpreted the meeting and the interview situation as an act of validation. It can be said that in a sense this is what had happened. However, the problem was that after the time of recording no one had ever contacted them again, did not say what happened to their stories. They had been archived and made available on the foundation's website, so it can be said that everything went as it should have. However, if you look at this issue from the point of view of the interviewees, being those representing these specific biographical experiences which for years had been strongly marginalized if not eliminated

\footnotetext{
${ }^{11}$ It was the only such concentration camp in Europe, whose prisoners were children from 6 to 16 years of age (in practice, also younger, 2-year-old children were imprisoned there). The camp existed from December 1942 until the Red Army entered in January 1945.
}

from collective memory, then such action can be considered not entirely ethical. Witnesses were treated as the story donors, not its subjects. This example illustrates very well, firstly, the illusiveness of the universality of certain procedural solutions, including those written in ethical codes, informed consents. Secondly, it emphasizes the need to assess the importance of the situation every time, not only in the methodological, but also in the ethical context. In this particular situation, leaving the interviewees to themselves can raise serious doubts, even if the action is taken in good faith and objectively can be socially useful as such.

Another important aspect of data inflation is the situation which concerns many researchers, including my professional experience. The contemporary work mode of research projects, which usually last two or three years, perhaps fits well within the framework of quantitative research, while in the case of qualitative and especially biographical research, this time limit in principle prevents the reliable use of collected materials. By reliable use I do not mean that the analytical work done during the grant period is unreliable. The point is that much of the analytical potential is not used due to the time pressure. When the project is finished, it is necessary to write a new proposal to meet the institutional requirements. Meanwhile, especially in the case of biographical research, the collected material could be used for research purposes for many years to come. It is in this sense that I have a feeling of the inflation of the biographical data which I have not used enough, although one of the most important conditions for a good narrative interview is to build a trust relationship based on the narrator's belief that his/her life story is important and unique for the researcher. We build this trust honestly, after which it turns out that we are not 
able to live up to this promise by archiving materials and not using their analytical potential. In my opinion, this is a very important ethical problem referring to both the relationship with the interviewee and to the work ethos when we are aware of putting away the empirical data which could be analyzed. An apparent solution to this problem is the implementation of computer analyses described earlier, enabling viewing large batches of material. However, it should be clearly stated that this is not what we agree on with our interlocutors and it is not about the agreement contained in the informed consent, but what a life story is in social, cultural, but also epistemic terms -it is an integral story built from the perspective of a specific wholeness. "The meaningful order of one's own life history has at its center the unfolding of one's own biographical identity in relationship to the overall 'gestalt' of concatenated and coexisting life historical processes" (Schütze 2008:9).

To some extent, the solution to this dilemma is the increasingly common practice of revisiting and reanalyzing. This is possible thanks to archiving and access to data collected by other researchers. The revisit may also refer to your own materials. In such case, again, it is difficult to talk about the unambiguity of the situation. The argumentation presented above shows the advantages of reanalysis and additionally gives sense to archiving-we have resources which we can come back to, which we can analyze after years, for example, critically or simply reflectively referring to the analytical work once performed. One example is the return to the texts and studies mentioned earlier: Biography and National Identity. In 2014, the team of researchers met again to comment on the analyses and articles created at that time from the perspective of the twenty years that have passed since the study was carried out. The result of the recorded discussion was published in $2016^{12}$ together with a reissue of texts published in 1996 and other articles which were published later on. The researchers had the opportunity to refer to their analyses written at that time and comment on their texts from the present perspective. Considering the contemporary scientific publishing policy, issuing such a book was not associated with increasing the authors' publishing output and the acquisition of additional points. Its value consisted in collecting scattered texts, showing the value of returning to the once collected materials, and above all-although this was not a clearly defined goal from the perspective of the issues discussed here-we "revived" the materials collected twenty years ago and thereby empowered their authors, that is, the narrators of their biographies.

The example shown is a form of a return visit undertaken by the same researchers. Therefore, it can be said that the original research context had been preserved and it is difficult to consider here, for example, a significant change in the analytical context and the new situation where there is a discrepancy between "to what people are being asked to consent, and to what they believe they are consenting" (Hammersley and Traianou 2012:89). It may then raise ethical dilemmas whether we are using the material in accordance with the narrators' informed consent (written or oral).

The same author points out, however, that the situation is generally difficult to be clearly determined because:

${ }_{12}$ Biografia i wojna. Metoda biograficzno w badaniu procesów społecznych. Wybór tekstów [Biography and War. The Biographical Method in the Study of Social Processes] (Dopierała and Waniek 2016). 
data are reflexively constructed within research processes rather than existing independently of these. From this point of view, data cannot be first collected and analyzed and then "re-used" by other researchers for the purpose of "secondary" analysis. Indeed, data cannot even be "collected" in the first place because they are always constructed...The conclusion drawn is that it is possible, and desirable, to use material that other researchers have generated; and that the process of analysis here is no different in epistemic status from that in primary research because the data are necessarily constituted, contextualized and recontextualized within any project. As a result, the problems of "fit" and "context" are no more likely to arise in research using data from an earlier study than they are in one where "new" data are produced. [Hammersley 2009:1-2]

Two conclusions follow this: firstly, even a return visit by the same researcher is always a new form of analysis. Of course, in my opinion, it is not a constructivist approach in the sense that it is difficult not to talk about a more permanent interpretative framework. Rather, the point is that the researcher's analytical view is each time contextualized by his/her experience, knowledge, and reflectiveness. This was clearly seen in the return to the above-described project Biography and National Identity.

Secondly, as I have already noted, it is difficult to clearly codify the relationship between the narrator and researcher concerning the interaction itself (neither the researcher nor the interviewee can project what will happen during the encounter, and how the story will emerge and be experienced by both) and then the analysis process. One should also take into account the fact that the narration becomes an element of a larger data collection and other life stories as a contrastive comparison also constitute the analytical context.

Another variant of secondary analysis is the researcher's return to other people's materials, which had been analyzed before. In the case of biographical research, this practice seems quite obvious in the sense that we can consider a specific type of autobiographical material, for example, narration, written autobiography, diary, and letters. In principle, all these data can be considered as independent cultural texts. ${ }^{13}$ Here, as an example we can point to the written autobiographies of the Chicago school, for example, The Jack Roller (Shaw 1966), or the autobiography of Władek Wiśniewski included in the $3^{\text {rd }}$ Volume of The Polish Peasant in Europe and America by William Thomas and Florian Znaniecki (1918-1920) - just to remind, the first research based on the biographical approach. Due to the centenary of its publication in 2018 the Department of the Sociology of Culture at the University of Lodz organized four seminars focused on the reanalysis of letters and the autobiography, as well as the authors' methodological and theoretical approach. The revisit after 100 years based on contemporary knowledge and new analytical approaches was very inspiring and enabled us to discuss both Thomas and Znaniecki's input and some mistakes they made. This example shows that it would be difficult to raise any ethical concern related to the data, whereas more ethical and critical com-

\footnotetext{
${ }^{13}$ Also in relation to some autobiographical narrative interviews one can say that they have become cultural texts. These are such narrations on the basis of which you can create the so-called portrait chapters and in analytical work they become special portrait case studies. This is because their subject is, for example, a life history, biographical experiences, the manner of storytelling, et cetera, exemplifying very well a specific social phenomenon or a specific type of biography. For example, such an interview is the narration of Hyüla, a Turkish immigrant to Germany (Schütze 2003).
} 
ments could be actually directed towards Thomas and Znaniecki (Waniek 2019). This kind of analysis helps to reflect on the development of ethical thinking and sensitivity which have developed in this case over time. Especially that today classic monographs based on autobiographies can be interpreted using contemporary procedures. Even if the reanalysis is critical, its aim is not to discredit the method used by the founders of the biographical method nor to question their results, but, on the contrary, to recognize them as fascinating and undeservedly forgotten (Czyżewski 1992:95-96).

\section{Concluding Remarks}

As I highlighted at the beginning, the purpose of this text is to join the ongoing discussion. First of all, I believe that this is a necessary discussion and considering ethical issues is a constant responsibility of every researcher in the course of their research. The direction of development of this reflection, outlined in the first part of the text, shows the constant tension between normative ethics, or as some researchers want-human ethics, and its posthuman alternatives.

Despite the suggestions of researchers of social sciences, especially qualitative sciences, it seems that the normative paradigm is not only dominant, but also becomes the basic frame of reference in the processes of institutionalization of science, to which we are increasingly subjected. I do not intend to refer to it in a generally critical way, putting alternative ethics in its opposition, which applies not only to the realm of (ethical) acting, but also to the realm of knowledge and "a broad socio-political philosophy which is at odds with that underpinning most social science" (Hammersley and Traianou 2014:9). The authors continue that in most cases researchers approve of "a liberal acceptance of the division of occupational tasks and responsibilities and the limits associated with these; and a distrust of utopianism in favor of a realism that emphasizes recognition of the constraints on action" (Hammersley and Traianou 2014:9-10). I entirely agree with this statement.

Therefore, what is the solution? In my opinion, there is no simple answer. The concepts of human ethics are worth considering as long as they do frame researchers' sensitivity and are not treated as a set of rules of ethical codes which will allow the researcher to protect him- or herself against the interference of ethics committees. In other words, the point is not about having complete documentation, completing all the formalities and losing sensitivity in the process of collecting material and contacting the research participants. Alternative proposals, on the other hand, may have the power to sensitize the researcher to the research situation, but respecting them also does not necessarily guarantee conducting research free from ethical tensions. Therefore, the basic reflection is the offer of constant discussion and sensitivity to the emergence of new problems and circumstances. Their examples are included in the second part of the text. I wanted to share them because, despite the growing attention which I try to devote to these issues in my work or discussions with other researchers, the issues presented in the article have, until recently, escaped my attention. I do not claim that these thoughts are insightful and introduce completely new problems to the discussion. Nevertheless, I treat sharing my reflection as an example, perhaps unfortunate because it is quite late, of the development of self-reflection associated with the observation of the dynamically changing frames in which one of the qualitative methods is used. 


\section{References}

Bertaux, Daniel. 1981. Biography and Society. The Life History Approach in the Social Sciences. London: Sage.

Burawoy, Michael. 2005. “For Public Sociology." American Sociological Review 70:4-28.

Czyżewski, Marek. 1992. "Uwagi o badaniach biograficznych [Comments on Biographical Research]." Pp. 93-100 in Bunty i stużebność uczonego: profesor Józef Chałasinski [Rebellion and Servitude of the Scholar: Professor Józef Chałasiński], edited by L. Wojtczak. Lodz: Wydawnictwo UŁ.

Denzin, Norman and Michael Giardina. 2007. "Introduction: Ethical Futures in Qualitative Research." Pp. 9-44 Ethical Futures in Qualitative Research: Decolonizing the Politics of Knowledge, edited by N. Denzin and M. Giardina. Walnut Creek, CA: Left Coast Press.

Dopierała, Renata and Katarzyna Waniek. 2016. Biografia i wojna. Metoda biograficzno w badaniu procesów społecznych. Wybór tekstów [Biography and War. The Biographical Method in the Study of Social Processes]. Lodz: Wydawnictwo UŁ.

Galewicz, Włodzimierz. 2009. “O etyce badań naukowych [On the Ethics of Scientific Research]." Diametros 19:48-57.

Gluza, Zbigniew. 2002. "Archiwa Społeczne [Social Archives].” KARTA 36:140-142.

Goble, Erika et al. 2012. "Habits of Mind and the Split-Mind Effect: When Computer-Assisted Qualitative Data Analysis Software Is Used in Phenomenological Research." Forum Qualitative Sozialforschung / Forum: Qualitative Social Research 13(2). Retrieved March 10, 2020 (http://www.qualitative-research.net/ index.php/fqs/article/view/1709).

Hammersley, Martyn. 2009. “Can We Re-Use Qualitative Data Via Secondary Analysis? Notes on Some Terminological and Substantive Issues." Sociological Research Online 15(1)5. Retrieved March 06, 2020 (http://www.socresonline.org.uk/15/1/5. html).

Hammersley, Martyn and Anna Traianou. 2012. Ethics in Qualitative Research. Controversies and Contexts. London: Sage.

Hammersley, Martyn and Anna Traianou. 2014. “An Alternative Ethics? Justice and Care as Guiding Principles for
Qualitative Research." Sociological Research Online 19(3)24. Retrieved March 06, 2020 (http://www.socresonline.org. uk/19/3/24.html).

Kaźmierska, Kaja. 2018. “Doing Biographical Research-Ethical Concerns in Changing Social Contexts." Polish Sociological Review 3:393-411.

Kincaid, Harold, John Dupré, and Alison Wylie. 2007. Value-Free Science? Ideals and Illusion. Oxford: Oxford University Press.

Klockars, Carl B. 2000. "Field Ethics for the Life History." Pp. 377-399 in Street Ethnography, edited by R. S. Wappner. Beverly Hills, CA: Sage.

Konecki, Krzysztof T. 2019. Advances in Contemplative Social Research. Lodz, Cracow: Wydawnictwo UŁ, Jagiellonian University Press.

Kohn, Tamara and Cris Shore. 2017. "The Ethics of University Ethics Committees: Risk Management and the Research Imagination." Pp. 229-249 in Death of the Public University?, edited by S. Wright and C. Shore. New York, Oxford: Berghahn Books.

Mead, Margaret. 1970. Culture and Commitment: A Study of the Generation Gap. Garden City, NY: Doubleday for the American Museum of Natural History.

Mauthner, Natasha S. 2014. “Digital Data Sharing: A Genealogical and Performative Perspective." Studia Socjologiczne 3:177186.

Mauthner, Natasha S. 2019. "Toward a Posthumanist Ethics of Qualitative Research in a Big Data Era." American Behavioral Scientist 63(6):669-698.

Merrill, Barbara and Linden West. 2009. Using Biographical Methods in Social Research. London: Sage.

Miller, Tina and Linda Bell. 2002. "Consenting What? Issues of Access, Gate-Keeping and 'Informed' Consent." Pp. 53-69 in Ethics in Qualitative Research, edited by M. Mauthner et al. Thousand Oaks, London: Sage.

Nora, Pierre. 1989. “Between Memory and History: Les Lieux de Mémoire." Representations 26:7-24. 
Ogburn, William F. 1922. Social Change with Respect to Culture and Original Nature. New York: B. W. Huebsch.

Potter, Van Rensselaer. 1971. Bioethics: Bridge to the Future. Englewood Cliffs, NJ: Prentice-Hall.

Przanowski, Karol. 2014. Credit Scoring w erze Big Data. Warsaw: Oficyna Wydawnicza SGH.

Rancew-Sikora, Dorota and Borys Cymbrowski. 2016. "W stronę socjologicznego ujęcia etyki badań naukowych [Towards a Sociological Understanding of Research Ethics]." Przegląd Socjologii Jakościowej 12(3):22-39.

Schütze, Fritz. 2003. “Hülya's Migration to Germany as Self-Sacrifice Undergone and Suffered in Love for her Parents, and her Later Biographical Individualisation. Biographical Problems and Biographical Work of Marginalisation and Individualisation of a Young Turkish Woman in Germany." Forum Qualitative Sozialforschung / Forum: Qualitative Social Research 4(3). Retrieved July 07, 2020 (http://www.qualitative-research.net/ index.php/fqs/article/view/671).

Schütze, Fritz. 2008. “Biography Analysis on the Empirical Base of Autobiographical Narratives: How to Analyse Autobiographical Narrative Interviews-Part One and Two." European Studies on Inequalities and Social Cohesion 1/2:153-242, 243-298; 3/4:6-77.

Shaw, Clifford R. 1966. The Jack-Roller. A Delinquent Boy's Own Story. Chicago: University of Chicago Press.

Szczepański, Jan. 1982. "Foreword." Sisyphus Sociological Studies 2:7-8.

Thomas, William I. and Florian Znaniecki. 1918-1920. The Polish Peasant in Europe and America, Vol. I-V. Boston: Richard G. Badger.
Tufte, Edward. 1990. Envisioning Information, Cheshire, CT: Graphics Press.

Ventura-Juncá, Patricio. 2011. “Science and Ethics: Bridge to the Future for Regenerative Medicine." International Journal of Stem Cells 4:79-84.

Waniek, Katarzyna. 2019. “Emigration of Władek Wiśniewski As an Escape-A Reinterpretation of The Polish Peasant in Europe and America Volume 3 in Light of the Autobiographical Narrative Interview Method." Przeglad Socjologiczny 4:49-73.

Wawrzyniak, Jan. 2005. “Aksjologiczność i etyczność nauk społecznych [Axiology and Ethicality of Social Sciences]." Człowiek i Społeczeństwo 24:59-76.

Wierzchoś, Dariusz. 2008. Zwyczajne życie zwykłych ludzi. Losy archiwum Towarzystwa Przyjaciót Pamiętnikarstwa [The Ordinary Life of Ordinary People. The Fate of the Archives of the Friends of Memoirs Society]. Retrieved March 10, 2020 (http://histmag. org).

Wiśniewski, Ryszard. 2005. “O trudnościach wpływania etyki na moralność, czyli o różnych wymiarach i granicach absolutyzacji i deabsolutyzacji etyki [On the Difficulties of Influencing Ethics on Morality, That Is, On Various Dimensions and Limits of the Absolutization and Deabsolutization of Ethics]." Człowiek i Społeczeństwo 24:29-42.

Zimmer, Michael. 2010. “'But the Data Is Already Public': On the Ethics of Research in Facebook." Ethics and Information Technology 12:313-325.

Żulicki, Remigiusz. 2017. "Potencjał big data w badaniach społecznych [Big Data Potential in Social Research]." Studia Socjologiczne 3:175-207.

\section{Citation}

Kaźmierska, Kaja. 2020. "Ethical Aspects of Social Research: Old Concerns in the Face of New Challenges and Paradoxes. A Reflection from the Field of Biographical Method." Qualitative Sociology Review 16(3):118-135. Retrieved Month, Year (http://www. qualitativesociologyreview.org/ENG/archive_eng.php). DOI: http://dx.doi.org/10.18778/1733-8077.16.3.08 